\title{
Javanese Traditional Market Cultural Value in Accounting World
}

\author{
Wiyarni $^{1}$, Iwan Triyuwono ${ }^{2}$, Unti Ludigdo ${ }^{3}$, and Ali Djamhuri ${ }^{4}$ \\ 1, 2, 3,4Faculy of Economics and Business, Brawijaya University
}

\begin{abstract}
This study explores the accounting values of Javanese traditional market and the potential extinction of those values that now are being marginalized by modern accounting. Modern accounting notions that only focus on economic value have lack meaning to a society whose need not only economic but also non economic value. This study uses grounded theory method to explore the Javanese traditional market values. This study found that tolerance which is consisted of hesitate and trust among traders in Javanese traditional market are the values that can be used in accounting as a concept to challenge the marginalization and domination of modern accounting notions.
\end{abstract}

Keywords: Javanese traditional market, tolerance, hesitate, trust, grounded theory

\section{Introduction}

Accounting is not an automatic gift and then to be something very significant as it appears today (Hopwood, 1994). The significance of accounting is created, established, maintained and preserved, and these all involve cultural rules and social practices. Hopwood (1994) argued that accounting research should give more consideration to the importance of the wider cultural and interpretative context of both accounting and accountant, because these shape the accounting practice and process of daily life. Forms of everyday life such as architectural, artistic, culinary, celebration or ceremony have very significant role in creating, maintaining and changing the domain of the accounting. By understanding cultural and everyday life broadly, it can help shed a little light on other areas of the accounting world.

Some accounting researches have responded to the Hopwood's statement and made the everyday life as hot topics in the accounting world. These accounting researches are Accounting and the construction of the standard house (Jeacle, 2003b); Accounting and the construction of the standard body (Jeacle, 2003a); Accounting and the Construction of Taste: Standard Labor Costs and the Georgian Cabinet-Maker (Jeacle, 2005); Face facts: accounting, feminism and the business of beauty (Jeacle, 2006); and Accounting and the annual general meeting: the case of the Edinburgh University Tea Club, 1920-45 (Jeacle, 2008). In addition to the Jeacle Ingrid studies, many other studies that make everyday life as the study of accounting, such as: From an envelope to a dream note and a computer-The award-winning experiences of post-war Japanese household accounting practices (Komori \& Humphrey, 2000); How to secure your husband's esteem, Accounting and private patriarchy in the British middle class household during the Nineteenth Century (Walker, 1998); Child accounting and 'the handling of human souls' (Walker, 2010); and Accounting at home: some interdisciplinary perspectives (Walker \& Llewellyn, 2000).

Another research that focuses on individual concerns and perspective is Walker's (1998) historical work. His study suggested that accounting featured prominently in the everyday life and culture of the middle class family in Britain during the nineteenth century. Based on his study he called researchers to:examine accounting as a social practice in the vast diversity of daily routines experienced by those that inhabit different social strata in various spatial, historical and contemporary setting (Walker, 1998).

In line with the above researches, following Walker's (1998) call and supporting Hopwood's statement about the significance of everyday life on the accounting science, this study aims to explore the accounting values inherent in everyday life of Javanese traditional market traders. The idea of this research is also inspired by Jacobs \& Kemp (2002) that assesses the presence and absence of accounting in the activity of small traders in Bangladesh. In his research, Jacobs \& Kemp (2002) found that the presence of accounting besides influenced by social factors and its institutionalization, it's also influenced by the ability to read and write of the traders. In addition, the level of social capital that defined as the norms and beliefs also plays an important role in determining the presence or absence of the accounting.

The existence of traditional market as a social institution has a strategic role in the development process of a nation (Bariarcianur, 2008). The participants (traders and buyers) of the traditional market have daily routines in doing business transactions that very different with those on modern retail market. Many gracious values inherent in the traditional markets that can be explored and used as a strategy to compete in today's global world, but very few studies that did it include research in the accounting field. Therefore, this study aims to explore the greatness of accounting values in the traditional market. By exploring the accounting 
values of traditional market, it is expected to give a space the Javanese local wisdom in the scientific world, especially in accounting world.

For the Javanese, traditional markets are the locus of their culture (Arifin, 2008). The traditional market is a cultural center that describes the expressions of attitudes and values inherent in its society (Bariarcianur, 2008). There is often seen that profit is not the primary goal, but rather a tool of spiritual fulfillment of the unity in each transaction. Communication and social interaction that exists automatically and then become the intimate relationship between sellers and buyers. Traditional markets can also be regarded as a living museum of cultural activities and day-to-day behavior that indicate how people within a community forming, shaping, and shaped by culture. In the Javanese traditional markets, interactions among individuals are intertwined in harmony, dynamic and synergistic through the economy wheels. The economy in traditional markets is less dependent on the business orientation or market interest alone. In the traditional market, we can see the presence of the unity in multiculturalism. In addition, the main characteristic of traditional markets is bargaining process, which is the basic democracy concept in building an agreement. Interaction in the traditional market reflects the Javanese trading ethos which is not fully emphasize in profit. All kinds of expressions of attitudes and values (include accounting values) are produced and marketed in the traditional market. This means that the accounting concepts that applied in traditional markets contain the cultural values of its society. Democratic nature and the unity of all participants in the traditional market will generate accounting concepts which is different from those used by modern shopping centers that are more materialistic and individualistic. In the traditional market, the trader is an actor who constructs the concepts of accounting in accordance with his/her beliefs, values and social norms. Meanings, attitudes, idealism, including accounting conceptual framework in the traditional markets are constructed through the interaction among the traders. Therefore, the traders are participants who actively create meaning (such as the accounting conceptual framework) that exist in the market.

Basically, the Javanese traditional market traders have the same characteristics with the informants Jacobs \& Kemp's study. However, the accounting concept of the traditional market traders besides come from their own personalities, it is also influenced by their environmental and cultural factors. Factors such as market operations, competitive conditions, selling system, interaction and transaction systems with buyers and with other sellers also influence their accounting concepts. Therefore, digging the accounting values of traditional market traders means exploring the values that exist in the traditional market. Choosing traditional market traders in this study besides to provide some light in understanding the accounting from the other side, it's also because the very lack of studies relating to traditional markets, especially from the accounting view.

Research about traditional market has been conducted by some researchers such as Anderson (1980); Dewey (1962); Kunjara (2005); Leksono (2009); Orr (2007); and Trappey \& Lai (1997), however, they tend to discuss about economy, marketing and the development of traditional market and none of them discuss from the accounting aspect. Dewey (1962) for instance, in her study about rural market networks in Modjokuto-East Java, provided several generalizations about the uniqueness of the market. One of her generalization stated that the market's system is durable and resilient. This system made the market still survived even in the economic distortions of the colonial period.

Javanese traditional markets which dominate the Indonesian urban markets now still exist although being marginalized by modern market such as supermarket. This study believes that the resilient of the traditional market besides because of its networks (Dewey, 1962) also its accounting values. Therefore, the objective of this paper is to explore the values and used them to challenge the modern accounting values that commonly apply in modern market. Traditional market is a particularly appropriate site to focus on in view of the controversy that surrounded the use of accounting notions in recent modern retail market. In this case, the emergence of accounting is based on its technical and calculative qualities rather than on the problems and priorities of the participants actively involved in the situation. By exploring the traditional market values, it can be understood why the modern market accounting conceptual such as materiality and monetary unit measure is not appropriate within the traders of traditional market. In the future, the Javanese traditional market values can be used as an accounting conceptual framework that not only useful for the Javanese or Indonesian company, but also for all the company in the world.

This paper is organized into three further sections. In Section 2, we outline the methodological orientation, research methods we used, and the specific sites. In Section 3, we elaborate and discuss the Javanese traditional market values and how they apply in accounting. This is followed by conclusions in section 4 .

\section{Grounded Theory Method To Explore The Accounting Values Of Traditional Market} Trader

This study claims that ontologically, accounting practice is a socially constructed reality that can shape, and be shaped by powerful actors and institutional environments. As a socially constructed reality, the organizational actors can construct their accounting practice to gain legitimacy and show that their organization 
operates in accordance with socially acceptable beliefs, values and norms. In this case, meanings, attitudes, ideals, including accounting concepts in the traditional market is constructed through the interaction between the traders. The traders (actors) cannot be totally objective because they are in the reality that subjectively constructed. Therefore, epistemologically, the accounting conceptual framework in the Javanese traditional market can only be obtained through the interaction among the traders as a market entity.

Based on the ontological, epistemological and human nature assumptions, this research uses a qualitative methodology. The process of collecting and analyzing data in this study uses grounded theory method. Grounded theory is a method of theory development based on action/interaction that making it suitable for the study of behavior (Cutcliffe, 2000). Grounded theory method focuses on thinking reflection that verbalized as the basis for understanding the social and interpersonal construction of decisions and daily activities of the actors. Grounded theory studies use data coding procedures thoroughly and carefully to increase the validity of data interpretation.

Grounded theory approach is also called constant comparative analysis, because theory development done in the same time with the process of data collection (Dimyati, 2000). Theory that generated by this method is inductively drawn from the phenomenon. This means that the theory was discovered and developed to be examined through systematic data collection and analysis of data relating to the phenomenon being studied.

Grounded theory using a sampling technique called theoretical sampling. Theoretical sampling is done by selecting the data or concepts associate with and support the theory that being developed. The goal is to take a sample of events/phenomena that show the categories, properties, and measurements that directly answer the research problem. Proposition is essentially a phenomenon that has been selected or searched and explored by researchers during the data collection. Because the phenomenon is inherent to the subject under the study, the number of subjects was increased until there was found no new information revealed by the last subjects. That is the reason why sampling subjects in grounded theory research, as well as qualitative research in general, can not be planned from the beginning. During the process, the subjects were determined in the field, when the data collection took place.

Furthermore, concepts, patterns and accounting processes of the traders themselves are defined through social interaction with other traders in the traditional markets. In this study, the sampled object is informant's understanding and activity relating with accounting concepts, such as the concept of determining profit/loss, the purpose of computing profit/loss, to whom the information gain/loss, the elements that determine profit/loss, considerations related with determining profit/loss, and so forth. The sampling process continues over time along with the data collection activities. Number of samples can continue to grow in line with increasing the amount of data required, for example until the compliance is achieved theoretically for each category.

The process of analysis in this study conducted in the form of coding (coding). Coding is necessary to make comparisons the similarities and differences of each event and is also useful for grouping based on the categories (Strauss \& Corbin, 1997). Coding is the process of decomposition of the data, conceptualize, and rearrangement in a new way. The objective of coding in grounded theory research is to: (a) develop the theory, (b) providing the accuracy of research process, (c) help researchers to overcome the biases and wrong assumptions, and (d) provide the foundation, giving the density of meaning, and develop sensitivity to generate theory.

There are two procedures of the coding process, they are: (a) the constant comparative method of analysis, and (b) asking questions. In the context of a grounded theory study, there are quite diverse things, which usually about: (i) the relevance of the phenomenon or data underlying problems that found in the research, and (ii) the position of any visible phenomenon of nature or size in a continuum level. In the process of this analysis, the researchers interpret the data obtained and also determine the categories that lead to the most appropriate accounting concepts of Javanese traditional market traders. In this phase, the researcher seeks to validate the number of categories. The result of in-depth interviews and active participation is the codes and the focus moves from the codes that are very descriptive to a more conceptual. The emphasis on the encoding process is to discover and explain the main variables more quickly and complete. Furthermore, as a result of the movement of the more conceptual codes is the main variable that appears faster with obvious relevance.

The site of this study was two Javanese traditional markets in South of Malang. The two traditional markets are Gedangan and Sumbermanjing Kulon. Until recently these markets still represent the culture and business ethos of Java community. These markets are the real market which their activities are driven by traditional economic actors in one building. From the institutional side, the markets are public community agencies that are loaded with economic motives. Their economic environment embodies the principles of exchange, reciprocity and distribution through mutual interaction among the traders and buyers. These markets have very different institutional traditions with modern market concepts. Their trading activities only on the particularly day of the five day Javanese market's day ${ }^{1}$ that have been prescribed for decades ago by their

${ }^{1}$ Javanese market's day is consisted of Pon, Wage, Kliwon, Legi, and Pahing. 
ancestors. Gedangan traditional market operates only each Wage and Pahing, whereas Sumbermanjing Kulon traditional market only on Legi. Beyond the appointed day, these traditional markets actually closed and not be operating at all. The specificity operation of these markets is the reason for researcher to use them as a research site.

The purpose of this study is to explore the accounting values of Javanese traditional market culture. The accounting values are constructed through the interactions among the traders. Here the traders in the traditional markets are also individuals who construct the accounting concepts. Therefore, the informants of this study are the traders of the traditional markets. The informants that selected for this study were four people who trade in these traditional markets. Three informants are Didiek, Mistam dan Samiyati who sales in the Gedangan traditional market, whereas another informant is Ken who sales in Sumbermanjing Kulon traditional market. Didik and Ken are chicken traders. Mistam is agricultural appliance trader and Samiyati is clothes trader.

To generate data that reflect the actual behavior of the traditional market traders and to get better feeling about how they construct accounting, the researcher acted as a person who assisted and accompanied one of the trader who sales chicken on the Sumbermanjing Kulon traditional market. While the data collection process in another market (Gedangan traditional market) was done by observation and in-depth interviews and occasionally researcher will act as a buyer. In the process of interaction with the traders in the traditional markets, researcher used communicative language to make easier in interaction and adjust with their habits. Conversation with the informants conducted with full of intimacy, with no objective research shows explicitly, by showing ignorance, and by providing a pause in any conversation so that they are able to reveal the actual information. In every conversation, researcher will slowly put the questions related the research so informants feel not being interrogate formally.

\section{Research Result and Finding}

The existence of accounting, besides influenced by the norms, beliefs, values and its institutionalization, it is also influenced by the culture. Culture is a factor that greatly affects the construction of accounting practice. Some researchers such as Hofstede (1991), Schein (2004), Taylor (2004), and Velayuthan \& Perera (1996) consider that accounting is a socially constructed reality, thus accounting practices cannot be separated from its cultural context. One approach that often used in the study of cultural dimension is Hofstede's cultural concept (1991).

Hofstede (1991: 5) defines culture as "the collective programming of the mind which distinguishes one group category of people from another." Furthermore, Hofstede (1991: 14) argues that there are four cultural dimensions, they are: individualism-collectivism, uncertainty avoidance, masculinity-femininity and power distance. Hofstede's cultural dimensions are the measurements that can be used to differentiate the values of one country to another. Based on this definition, the purpose of this study is to place the Javanese traditional market culture in accounting.

Human cultures can be either languages, objects, colors, sounds, or actions (Herusatoto, 2008). In Java, there are two basic principles of the social relationships that reflect a virtuous life. The principles are the harmony (rukun) and respect. Harmony means calm and serene, without strife and conflict (Suseno, 1997). Mulder (1978) defines rukun as:

Rukun is soothing over of differences, cooperation, mutual acceptance, quietness of heart, and harmonious existence. The whole of society should be characterized by the spirit of harmony, but whereas its behavioral expression in relation to the supernatural and to superiors is respectful, polite, obedient, and distant, its expression in the community and among one's peers should be akrab (intimate) as in a family, cozy, and kangen (full of the feeling of belonging).

Respect is the use of language or conversation and behavior that should reflect respect for those who fall into social contact (Suseno, 1997).

Based on the results of the data collection process, there are 16 conceptual codes which is the result of open coding. Almost all of the codes occur repeatedly, while only a few are just once, for example rejeki kedah bagi roto (the fortune should be share). In the majority, the codes are considered as the property of conceptual categorization process. During the process of axial and selective coding, the codes are filtered into one conceptual category; it is among roso (tolerance). Below is the table that explains the result of open, axial and selective coding process. 
Table 1

Data Categories

\begin{tabular}{|c|c|c|}
\hline $\begin{array}{c}\text { Open Coding } \\
\end{array}$ & Axial Coding & Coding \\
\hline $\begin{array}{l}\text { 1. Share the fortune (rejeki } \\
\text { kedah bagi roto) } \\
\text { 2. Harmony (rukun) } \\
\text { 3. Hesitate (sungkan) } \\
\text { 4. Helping (nulung) } \\
\text { 5. Tolerance (teposliro) } \\
\text { 6. Increasing family (nambah } \\
\text { sedulur) } \\
\text { 7. Trust (percados) } \\
\text { 8. Conversation (ngobrol) } \\
\text { 9. Produced by themselves } \\
\text { (membuat sendiri) } \\
\text { 10. Ask other people to make it } \\
\text { (mburuhaken) } \\
\text { 11. Compete in quality (sae- } \\
\text { saean) } \\
\text { 12. Small profit but frequently } \\
\text { (bathi sekedik tapi ping } \\
\text { kathah) } \\
\text { 13. Help friends (mbantu } \\
\text { rencang) } \\
\text { 14. Understanding (kedah } \\
\text { mangertos) } \\
\text { 15. Hesitate to the others } \\
\text { (sungkan kalian lintune) } \\
\text { 16. Not all people like money } \\
\text { (mboten sedoyo tiyang } \\
\text { remen arto) }\end{array}$ & $\begin{array}{l}\text { 1. Hesitate } \\
\text { 2. Trust }\end{array}$ & TOLERANCE \\
\hline
\end{tabular}

\subsection{Tolerance as A Transaction Principle of Traditional Market Traders}

Traditional market people lifestyle is very simple and likes to socialize with other people. The interaction principle among the traditional market traders are a sense of tolerance, mutual help and friendly without any losses each other. Relationships between traders and buyers require a special relationship and merchants usually have regular customers that called special customer (langganan). Boisterous bargaining is a "spirit" market dynamics. This condition distinguishes traditional market with a modern shopping center. Seller and buyer relationships in a modern shopping center are not impersonal social interaction. In modern market, visitors tend to get away after getting the stuff (Lilananda, in Yuniman \& Wahjudy, 2006). Many people do not realize the benefits of bargaining system. Bargaining system actually make people able to provide an important psychological impact for the community. Any person who acts in a transaction will involve all the emotions and feelings that cause social interaction, laughing, frowning, and even debating.

Economic relationship among the members of the traditional market traders also can be seen through borrowing and lending without interest. The merchants of the traditional markets compete for getting the customers but they are still as a good friend (Lilananda in Yuniman \& Wahjudy, 2006). It can be concluded that the traditional market has its own unique character which is in line with the Indonesian people who are still interested in socializing. Generally, buyers already have a special trader and vice versa. If they are not satisfied with the item purchased, they can complaint the merchant directly. The nice and close relationship among members in the traditional market is one of its powers (Djau, 2009).

Based on the coding process, this research finds that tolerance (among roso) is the cultural value of Javanese traditional market traders in doing their transactions. This value is held by traditional market traders in both interacting and transacting with buyers, suppliers or with fellow traders. In Java, there is a wisdom called 'Tata Tentrem Kerta Raharja' which means invites us to realize our desires in orderly manner, without causing turmoil and without creating something that can make the situation become disharmony (Amrih, 2008). Examples of such behavior are: not overbearing, not act without ethics, or not interfere with the others' rights. This wisdom appears on the behavior of traders when they interact and transact with others. They always keep the feelings of others (among roso) in every decision they made. 
The tolerance is reflected in how they respect or appreciate the decision of the buyers or fellow traders. They would appreciate if the buyer did not choose the goods that have been compromised and switched to another vendor that is located near them. Embodiment of tolerance is evident in a harmonious market conditions. The harmony seems to flow in a variety of activities, for example, if other traders have a problem or have a particular event, they will help them. In addition they are most likely to borrow money or merchandise for a smoothness of their business. Mutual trust is also a factor that has a contribution in the harmony of traditional markets. The traditional market traders always help other traders with very happily if they need to go to bathroom, prayers, or other purposes. In this case, the trader who needs some help never suspected to trader who keep the merchandise. The tolerance value among traders in Javanese traditional market can be seen through their hesitation and trust attitudes. Below are the explanations of the two attitudes.

\subsubsection{Hesitate as A Competition Control in Traditional Market}

Most of the traders in traditional markets close each other with selling the same product. This is the emerging wisdom where traders find a buyer. There is a feeling embarrassed that arise when they are faced with the challenges to compete for the consumer or buyer. They do not want to snatch customers from other traders. They feel free to ask the buyer to move them before the buyer really does not fit with previous merchant. They allow buyers to decide to whom they want to buy. The relationship between the merchants who sell the similar goods is not a competition but rather a partnership relationship. They consider the merchants that sell the same products as partners. Here is the answer when asked how traders deal with the buyer who wants to move to the other traders.

"It's okay, life should be equal, live together should be in harmony, if we want to compete, better compete in terms of goods quality." (Mistam)

Gedangan traditional market operates only twice (Wage and Pahing) for five-day period and SumbermanjingKulon market operates only one day on Legi.. Therefore, the traders have opportunities to sell to the other markets that have different day operation. However, all informants in this study do not sell to the other market with the reasons:

"If I am selling everywhere, the income of the traders in there will be decrease." (Mistam)

"I feel hesitate when I sell in other markets, although it is OK for the traders over there." (Didiek)

Based on the answers above, we can see that Didik and Mistam worried about reducing the income of the traders in other markets if they sell there. They actually wanted to get a higher profit, but they have a feeling to share their revenue with other merchants. This behavior or attitude certainly does not appear in the modern market, it can be seen by many modern retails that located close each other. In addition, for the street vendors, they are free to occupy any place they want without having to sign up or buy the place. In this case, the original or old vendors of the market don't want to complain even though their income may be reduced by the new traders, because they believe that if it's their fortune, so it never go to anywhere. On the other hand, even new street vendor also know how to have position on the market that is not their location.

\subsubsection{Trust as An Empowering Social Capital Principle}

In the traditional market, social capital is created by business life tradition which is the basis of the traders to act in their daily activities. Trust is one of the values that can create the traditional market's patterns and norms. As a social being, a merchant and the buyer or as a human being are need others, and there is a tendency for them to be able to cooperate and interact with each other, including in terms of transactions. Therefore, it is necessary to have these values and norms as a base to behave, so that they can live together and have a mutually beneficial.

By maintaining the values and norms of honesty, mutual trust, consumer and trader cooperation, it will create superior economic performance in the traditional market. Glasser et. al (in Laksono S 2009:121) states that trust is the basis to strengthen cohesion and social capital. Trust is a basic capital that is the basis of the social capital itself. With the trust, it will come up with expectations. Through expectations based on trust, it can also build a partnership. Having the trust, it is also possible to have a business transaction. As an object or process, trust is always associated with the norms and networks, because these three are central to the social capital.

Social capital is a growing capability derived from a common belief in a community environment. According Torvsik (in Laksono S 2009: 123), trust contains certain behavior that tends to reduce the risks that arise from the behavior. Trust is an asset. The good business economically can be measured by fulfilling the legal system and moral norms at least meet three benchmarks, namely: a) is not contrary to conscience, which is something (value) associated with the deepest conviction; b ) for objectivity, it is needed other norms, that is "treat others as yourself as you want to be treated, and vice versa", c) for its effectiveness, is also needed a general assessment or a community assessment. Humans are not only just a homo economicus, there are still other aspects that are very important in determining patterns of behavior and actions in doing the business. 
There are certain values and norms that define and drive the performance of their merchandise (Laksono S: 2009).

For those who trade in the traditional markets, the bargaining process is also a mode of interpersonal communication over an exploratory, open network, build mutual trust in order to obtaining price certainty. Almost all of traders in Gedangan and Sumbermanjing Kulon have a good relationship of trust. Of course not only the traders who are required to have a sense of confidence in the buyers, but to be profitable on both sides, the buyer is also required to have the confidence to traders. Thus it will create a sense of mutual trust between the two sides. Expected from the social capital of trust that can be profitable for both parties and the buyers are expected to continue to survive choose where to shop in the traditional markets to keep and maintain the existence of the traditional market.

\subsection{The Impact of Tolerance to The Profit Recognition}

Generally, profit is the difference between revenues and expenses. The amount of profit is usually measured by the number of dollars or in terms of materials. Process to gain maximum profit in a company typically depends on the meaning and the elements of profit itself. In the community or communities that define the profit as the amount of dollars or material received, the process to get the maximum profit would typically be done by managing the numbers on which to base the calculation and ignore non-material factors such as harmony and friendship. For example, increasing profit can be done by raising prices or by lowering the cost that both of them are main elements in calculating profits. This formula is different from a society or community who define profit is not only material, but there are other values that are also recognized as profit.

In Javanese traditional market, the traders interpret the profit is not only in the form of material but the value of relationship and friendship is also a part of their profits. Meaning of wealth for the traditional market traders attached to the trade concept known as "tuna sathak bathi sanak (small profit with, but a lot of relatives or friends)". It means that no problem for them not to get high profit but they have more friends. The implication of this concept is the traders often sell with lower prices (low profit) as long as they can keep the customer for ever. The tolerance that consists of hesitates and trusts tend to increase their relatives and friends rather that increasing their profit.

\section{Conclusion}

The traditional market traders do not count even record or report their earnings because they profit or advantage not only measured by money alone but also the relationships, relatives, friendship and harmony. Pricing decision in a traditional market is very simple because the traders automatically have a deal with a fellow merchant to sell at the same price. This is the uniqueness of the traditional markets, the traders do not discuss to determine how much the selling price of their goods, but they are always sold at the same price and if they will change the price for example during the day, then it will also occur simultaneously. This is the mirror of harmony among traditional market traders; they are not competed each other although they sell the same goods.

The traditional markets are still exist even though the monetary crisis conditions. This is because of their social values. Social capital is a value that should be maintained and appointed as awareness that there is a strategy to face the globalization. Global economic order can certainly be understood as a necessary utopia or threats spawned optimism and pessimism. The traditional market is evidence of positive resistance to conditions of life that lead times are pragmatic and materialistic.

Finally, it can be concluded that the role of traditional market on the basis of cultural values in order to legitimize the system and realize the economists in the populist orientation and well-being. The role is a realization of the existence of the traditional markets as economic transactions space, the space of social interaction, communication room, and entertainment room (art). There are several reasons for the consumers still prefer traditional markets. Some of these reasons are culture, history, easy to reach, price negotiable or owed first, a sense of family is quite high, and the traditional markets also offering business opportunities and jobs. This is the positive side that cannot be separated from the potential social, cultural, and economic values, which make traditional market include its accounting concepts able to exist in this era of modernization.

\section{References}

[1]. Arifin, Y. 2008. Jogja dan Budaya Pasar. $\quad$ Retrieved $16 \quad$ Mei, 2011, from http://iyanfukuyama.multiply.com/journal/item/15/Rekonstruksi_Budaya_Pasar

[2]. Anderson, A. G. 1980. "The Rural Market in West Java." Economic Development and Cultural Change 28(4): $753-777$.

[3]. Bambang Djau, ST, 2009. "Seminar Nasional Menuju Penataan Ruang Perkotaan Yang Berkelanjutan,Berdayasaing, dan Berotonomi”. Seminar Nasional Perencanaan Wilayah dan Kota ITS, ISBN No. 978-979-98808-2-6

[4]. Bariarcianur, F. 2008. Festival Budaya di Pasar Tradisional. Retrieved 18 Mei 2011, from http://id.wordpress.com/tag/festivalpasar-kumandang-solo

[5]. Cutcliffe, John. R. 2000. Methodological Issues in Grounded Theory. Journal of Advance Nursing (31)

[6]. Dewey, A. G. (1962). Peasant Marketing in Java. New York: The Free Press of Glencoe, Inc. 
[7]. Dimyati, M. 2000. Penelitian Kualitatif: Paradigma, Epistemologi, Pendekatan, Metode, dan Terapan. Malang: Universitas Negeri Malang.

[8]. Hofstede, G. 1991. Cultures and Organisations; Software of Mind. McGraw-Hill, New York, NY.

[9]. Hopwood, A. G. (1994). Accounting and Everyday Life: An Introduction. Accounting Organizations and Society, 19(3), 299-301.

[10]. Jacobs, K., \& Kemp, J. 2002. Exploring accounting presence and absence: case studies from Bangladesh. Accounting, Auditing \& Accountability Journal, 15(2), 143-161.

[11]. Jeacle, I. (2003a). Accounting and the construction of the standard body. Accounting, Organizations and Society, $28,357-377$.

[12]. Jeacle, I. (2003b). Accounting and the construction of the standard house. Accounting, Auditing \& Accountability Journal, 16(4), 582 .

[13]. Jeacle, I. (2005). Accounting and the Construction of Taste: Standard Labour Costs and the Georgian Cabinet-Maker. ABACUS, 41(2).

[14]. Jeacle, I. (2006). Face facts: accounting, feminism and the business of beaty. Critical Perspectives on Accounting, 17, 87-108.

[15]. Jeacle, I. (2008). Accounting and the annual general meeting: the case of the Edinburgh University Tea Club, 1920-45. Accounting History, 13(4), 451-478.

[16]. Komori, N., \& Humphrey, C. (2000). From an envelope to a dream note and a computer-The award-winning experiences of postwar Japanese household accounting practices. Accounting, Auditing \& Accountability Journal, 13(4), 450.

[17]. Kunjara, E. 2005. "Gender and Assertiveness: Bargaining in the Traditional Market in East Java." Women and Language $28(1)$ : 54.

[18]. Leksono, S. 2009. Runtuhnya Modal Sosial, Pasar Tradisional: Perspektif Emic Kualitatif. Malang: CV. Citra.

[19]. Mulder, Niels. 1978. Mysticism and Everyday Life in Contemporary Java: Cultural Persistence and Change. Singapore: Singapore University Press.

[20]. Orr, W. W. F. 2007. "The bargaining genre: A study of retail encounters in traditional Chinese local markets." Language in Society 36: 73-103.

[21]. Schein, E.H. 2004. Organizational Culture and Leadership. 3 ed. San Francisco, CA: Jossey-Bass.

[22]. Strauss, A., and Corbin, J. 1997. Basics of Qualitative Research: Grounded Theory Procedures and Techniques. Yang telah disadur oleh Djunaidi Ghony, Dasar-dasar Penelitian Qualitatif: Prosedur, Teknik, dan Teori Grounded. Surabaya: Bina Ilmu.

[23]. Suseno, Magnis, F. 1997. Javanese Ethics and World-View: The Javanese Idea of the Good Life. Jakarta: PT Gramedia.

[24]. Taylor, C. 2004. "The Power of Culture: Turning the Soft into Business Advantage," in The Power of Culture: Driving Today's Organization. R. Coy (Eds). Sydney: McGraw Hill: 1-35.

[25]. Trappey, C. and M. K. Lai 1997. "Differences in Factors Attracting Consumers to Taiwan's Supermarkets and Traditional Wet Markets." Journal of Family and Economic Issues 18(2).

[26]. Velayutham, S. and Perera, M.H.B. 1996. The Influence of Underlying Metaphysical Notions on Our Interpretatation of Accounting, Accounting, Auditing and Accountabiltiy Journal, 9 (4): 65-85.

[27]. Walker, S. P. (1998). How to secure your husband's esteem. Accounting and private patriarchy in the British middle class household during the nineteenth century* Accounting, Organizations and Society, 23(5/6), 485-514.

[28]. Walker, S. P. 2010. Child accounting and 'the handling of human souls'. Accounting, Organizations and Society, 35, 628-657.

[29]. Walker, S. P., \& Llewellyn, S. 2000. Accounting at home: some interdisciplinary perspectives. Accounting, Auditing \& Accountability Journal, 13(4), 425

[30]. Yuniman dan Wahyudi. 2006. "Analisa Perkembangan Pasar Tradisional (Studi Komparatif Terhadap Penggunaan Ruang Komersial di Pasar Atum, Pasar Turi dan Pasar wonokromo)”S. Skripsi Jurusan Manajemen Universitas Kristen Petra Surabaya. 